\title{
RESET
}

Recherches en sciences sociales sur Internet

$8 \mid 2019$

Genre \& Internet. Sous les imaginaires, les usages ordinaires

\section{Doing Gender Online. Ordinary Practice Beyond Utopian Ideals}

Introduction

Marie Bergström and Dominique Pasquier

\section{OpenEdition}

\section{Journals}

\section{Electronic version}

URL: http://journals.openedition.org/reset/1804

DOI: $10.4000 /$ reset. 1804

ISSN: 2264-6221

Publisher

Association Recherches en sciences sociales sur Internet

\section{Electronic reference}

Marie Bergström and Dominique Pasquier, « Doing Gender Online. Ordinary Practice Beyond Utopian

Ideals », RESET [Online], 8 | 2019, Online since 01 June 2019, connection on 25 August 2019. URL :

http://journals.openedition.org/reset/1804; DOI : 10.4000/reset.1804

This text was automatically generated on 25 August 2019.

(C) Association Recherches en sciences sociales sur Internet 


\title{
Doing Gender Online. Ordinary Practice Beyond Utopian Ideals
}

\author{
Introduction
}

\author{
Marie Bergström and Dominique Pasquier
}

1 Does the Internet change or reproduce gender relations, understood as the norms and the practices that differentiate and hierarchize between women and men? How so? These questions are at the core of the current issue of RESET, dedicated to ways of "doing gender online". The aim is to both question the gendered use of new technology and revisit the theoretical perspectives of gender studies through the lens of digital practices. This issue echoes the perspectives of a 2003 article by Josiane Jouët, "Communication Technologies and Gender. Relations under construction", published in the special issue "Gendered communication" of the French journal Réseaux (Jouët, 2003). In her article, Jouët provided a critical and truly international literature review that showed how gender structures technological design, and the ways usage is sexually differentiated. Drawing on her reflections, the present issue showcases recent work on the topic; reading the ensemble of article, we observe both continuity and change.

The call for papers attracted 46 proposals, of which around a quarter were in English. The large number of articles shows the importance of the topic in the eyes of social scientists. It stands in sharp contrast with the statement made by Josiane Jouët almost twenty years ago when she pointed out that "to answer our questions, there are few French studies; there is no established body of research (...) on gender and communication" (Jouët, 2003. 55). Nowadays, studies of gender relations, or at least studies mindful of this perspective, are common in France, including among Internet scholars. However, this has not led to a specific subfield of research. There are two main reasons for this. First, the gender perspective has spread beyond the circle of "gender studies" and is today widely used in research on various topics, like economy, family, work, sexuality, etc. Second, the increasingly pervasive nature of digital technologies - which have become a central part of daily life - has made it an object of study for a large number of sociologists. The proposals in response to our call for papers attest to this: for the most part, the authors are not Internet scholars but experts in other fields. This proves true, as well, for the 
articles published in this issue, showing us both the realm of contemporary Internet use and its profoundly gendered nature.

\section{The slow change of gender stereotypes online}

Seldom has a technology raised as many hopes as the Internet. The development of this "network of networks", originally set in North America, spread enthusiasm among social scientists for the possibilities of social transformation that it seemed to offer (Rheingold, 1993; Turkle, 1995). This enthusiasm was especially strong among feminist scholars who immediately considered the Internet as a space for changing gender norms. Contemporary to the development of "gender studies", the Internet was seen to create "gender trouble", as Sherry Turkle put it (1995) in reference to the founding work of Judith Butler (Butler, 2002). Online communication, it seemed, offered a possibility to dissociate the physical body (male/female) from gender identity (man/woman) and resulted in more fluid identities, calling into question gender binarity. Thus, in the mid-1990s, Allucquére Rosanne Stone declared that "in cyberspace the transgendered body is the natural body" (Stone, 1995. 181). Twenty years later, while the enthusiasm surrounding the Internet has faded, the image of the online world as a space for subverting gender relations persists. Empirical research on the Web 2.0, however, often indicates a reproduction of gender stereotypes that are already present offline. "The gendered division of the world into two complementary and antagonistic sub-worlds", described in Isabelle Clair's work (Clair, 2007. 157; 2012), resonates with Claire Balleys' research on gender performances among young YouTubers (Balleys, 2017). Her study of these YouTubers does not indicate a subversion of gender roles but rather reveals a strong attachment to gender binarity (Balleys \& Coll, 2015; Balleys, 2016, 2017).

4 Similarly, the principle of "female vulnerability" highlighted by Aurélia Mardon (2010, 2011)regarding young adolescent girls studied at school and in the families offers a direct parallel with the duty of "female reserve" observed on heterosexual dating sites and applications (Bergström, 2012, 2019). Thus, in contrast to sociological texts that take public discourses regarding the so-called upheavals induced by the Internet at face value, whether to claim the end of traditional social assignments or to deplore the commodification of relationships (Illouz, 2007, 2012), these studies, based on different investigations, reveal a substantial continuity in behaviour and interactions between the sexes. Online, as well as offline, gender relations remain characterised by the dual principle of opposition and complementarity between the sexes. Far from being an exception to the gender relations that structure offline settings, the digital universe is underpinned by power relations, inequalities and struggles that we observe elsewhere; often, it emphasizes them.

5 This is what Dina Pinsky strikingly highlights in her article for this issue. The paper is based on a central question: does the distance between bodies in digital interaction open up for "sexual scripts", in the sense of Gagnon and Simon (Gagnon \& Simon, 2005 [1973]), different from those that can be observed face-to-face? The survey is based on interviews, both individual and in focus groups, with 53 students from a college in Northeastern United States about their online "flirt" relationships. The collected verbatim leaves no ambiguity: the principle of female modesty and the male prerogative of initiative to sexual contact remain intact on the Internet. Women must express their sense of attraction in euphemised forms (e. g. by emojis expressing emotions or with 
compliments), and those who go beyond this normative framework, by making more explicit sexual demands, suffer a social sanction that directly affects their reputation online and offline. The same reputation discredit affects male students who venture out of bounds and make sexual demands too quickly or too explicitly, such as sending naked photos. In short, Pinsky teaches us, scripts for digital flirt closely reproduce the traditional frameworks of seductive relationships between women and men. However, and this is where this survey is particularly original, this statement holds regardless of the sexual identity of the interviewees: in her sample, the 18 students who declared themselves bisexual, homosexual or transgender express the same expectations towards their partners. This can make the period of seduction more complex when, for example, two women flirt with each other while both respecting the principle of female reserve.

The gendered relationship to technological tools is another area of research where empirical results often contradict hopes for new forms of equality. Several studies have shown gender differences in girls' and boys' "computer socialization", and how these differences lead women to lack confidence in their skills. Sherry Turkle gave a precise description of this female "reluctance", which she observed even among female students in a computer science program at Harvard, who said they refused to have a strong involvement with a machine (Turkle, 1988). The gender stereotype associates technology with men. Nicolas Auray's work in France on groups of geeks and hacker communities, shows that these are almost exclusively male, often misogynists (Auray, 2002, 2013). Computing and programming are still highly male-dominated occupations. In France, 4 computer engineers and technicians out of 5 are men ${ }^{1}$. This has not always been the case. Up to the 1980s, women were relatively well represented in the IT sector in Europe as well as in the United States. This was a time when corporate IT was operated through office automation activities carried out by female secretaries (Collet, 2006). Subsequently, these IT occupations experienced a massive influx of men as jobs gained in prestige, highlighting the links between gender distribution and occupational representation (Collet \& Mosconi, 2010; Misa, 2011; Abbate, 2012). The development of the Web and of the Internet economy - as illustrated by the Silicon Valley - does not seem to have significantly changed this trend.

7 There are also usage scripts targeting men in many technical artefacts even though they are supposedly designed "for everyone" (Oudshoorn et al., 2004; Marwick, 2013). The video game sector, which is a major one in the technology industry, is particularly interesting in this respect. For boys, playful practices have traditionally been a form of introduction to the computer world (Jenkins, 1998) and major surveys show higher rates of play among men, especially young men, although the development of smartphone games has significantly contributed to a feminization of the practice (for France, see Donnat, 2009; Gire \& Granjon, 2012; Mercklé \& Octobre, 2012). In the academic literature, the highly gendered nature of video games has often been addressed through the prism of design and avatars, which are often sexualized and follow traditional gender stereotypes (Cassell \& Jenkins, 2000; Kennedy, 2002). The video game industry is in fact a way of understanding the interplay between design and usage. Two articles in the current issue, one by Chloé Paberz and one by Johann Chaulet and Jessica Soler-Benonie, contribute to demonstrate the deeply rooted dimension of male domination in the world of video games, both on the creative side and on the user side.

8 In her ethnographical study, Chloé Paberz followed the daily life and interactions between male and female employees in a small video game design company in South 
Korea. The country owes its economic boom to the technology sector, and the proportion of women working in development studios, although a minority (27\%), is higher than elsewhere (15\% in France for example). On the other hand, the rules of gender distinction in Korean society are much more pronounced than in Western societies. Chloé Paberz's study therefore offers two highlights. The first one is the place of women in a culture where they are assigned to a subordinate position in relation to men. The second is the revelation of the foundations of a male professional culture that has "endowed itself with references, values, rituals, reserved spaces and moments where masculine qualities, tastes and skills are cultivated". Through the article we are entering a world where women's professional handicaps are played out through tiny prohibitions that have enormous career consequences, such as the impossibility, without damaging their personal reputation, of staying late at night in the company when there is overwork, or the exclusion of all moments of social life that tie teams together at work, such as after work outings with colleagues (notoriously important in East Asia). It is also a world where the strength of gender stereotypes tends to make it unthinkable for a woman to occupy a professional position other than hostess (a female manager is described as a "monster"), where female video game enthusiasts are stigmatised, especially if they demonstrate virtuosity ("the tomboy"), and where eroticized representations of female characters are systematically staged in the games themselves.

Johann Chaulet and Jessica Soler-Benonie conducted interviews and observations during Local Area Network tournaments (LAN) of League of Legend. The female figures they identified at these events are surprisingly similar to those that prevail in the company studied by Chloé Paberz. The female players, who are very few in number $-4 \%$ of all players! - have a choice between two postures: that of a tomboy who adopts the same dress codes as male players (hoodie and jogging), or that of a hyper-feminized lolita (miniskirt and heavy make-up). The other women present in the tournaments are either hostesses, volunteer staff or supporters, especially for teams including their boyfriend: by their presence, they contribute to nuance the negative figure of the solitary and asocial geek. This reproduction of female domestic roles in the arena of the game is matched by a male gender parade among players, detected both in the qualities associated with playing skills (surpassing oneself, competition, combativeness, expert handling of technique) and in the sexist and sexual vocabulary used throughout the tournament.

These three articles, to say the least, do not open many options to emancipation from gender stereotypes. Should we consider that, not only has nothing changed, but worse, that the online settings reinforce male domination, particularly because of the technical dimension of the tools? The answer is no. The practices observed are like a house of cards: men struggle for a territory they have partially lost while pretending to be the only master upon it.

First, women's reluctance to technology disappears when machines become "invisible": a simple tool and not a technology to be mastered (Singh, 2001). A good example of this is the extremely rapid catch-up of women in digital practice, due to the massification of Internet use and the simplification of its access modes (smartphones and tablets). Laurence Le Douarin's work also shows that "the computer reveals, in male/female relations, more ideology in skills - affirmed for some, denied for others - than in actual reality" (Le Douarin, 2004. 155). Although the massive feminization of video games was largely brought about by games on smartphones, located at the bottom of the hierarchy of games because they are disqualified as "girls' games", we have seen at the same time 
the emergence of the figure of the gamer girl, passionate and efficient in a male sector like massively multiplayer online role-playing games (Lignon, 2015). Perhaps we must assume, as does Sylvie Octobre, that digital practices reconfigure representations of femininity and masculinity through a dual movement where girls gain access to tools considered "masculine", because they are technological, and boys enrol in traditionally female activities, like writing and conversation (Octobre, 2011). While women's incursions into traditionally male territories, such as video games, are beginning to be documented, there is a lack of research on the opposite phenomenon.

\section{Doing ordinary gender: perspectives on gender relations and their evolution}

In his article entitled "A Sociology of the Unmarked: Redirecting Our Focus", Wayne Brekhus highlights the tendency of social scientists to focus more on extraordinary social phenomena than on mundane ones (Brekhus, 1998). His analysis stands as an internal critique to the sociological discipline, and points to the disproportionate attention paid to certain groups and behaviours with regard to their prevalence. Although sociologists aim to deconstruct preconceived notions, considered as "epistemological obstacles" that need to be overcome (Bachelard, 1938), they often study phenomenon that are salient (because unusual, disturbing or exotic) and therefore already "marked". The consequence of this is not only that certain populations and practices enjoy greater visibility than others, which might be more numerous or ordinary, but also a tendency to generalise from certain social actors:

Although politically radical, this approach is still cognitively conservative in maintaining the epistemological ghetto that highlights the marked. Whether radical or conservative, for instance, studies of members of marked categories such as African Americans, homosexuals, the poor, women, youth, and the elderly rarely generalized to conclusions about "social actors" writ large. Studies of whites, heterosexuals, the middle-class, men, and nonelderly adults, by contrast, are routinely abstracted to generic human social relations. In theory, the study of marked populations is, however, no less generalizable to human social behavior as a whole than the unmarked populations (Brekhus, 1998. 41).

Gender studies are illustrative both of this trend, and of the efforts to recalibrate the attention given to different aspects of social life. Historically centred on women, they have sometimes paradoxically participated in the invisibility of men as the "unmarked" (Alonzo \& Silvera, 2000). The spread of queer studies in the 90s meant a broadening of topics and groups of study. Often interested in sexual minorities, authors shed lights on the norm by looking at those who do not conform to it. This scientific approach has proven both efficient and heuristic; however, it fails to account for majority groups and behaviours. Among the literature on sexuality, for example, there now seems to be more works on homosexual young men than on heterosexual mid-aged men, precisely and paradoxically because the latter are considered to be the norm. In this regard, the more recent development of masculinity studies opens up for new perspectives. Drawing on the work of Raewyn Connell (2005), and taking on a relational approach to gender, authors take interest in the hierarchies within the group of men. In doing so, they highlight both the hegemonic and subordinate forms of masculinities. Easily transposable to the study of femininities, this research agenda allows for studies on the continuum of marked and unmarked phenomenon. 
In line with this approach, the current issue called for articles on "ordinary" practice, according to Brekhus definition of the "unmarked". This angle seemed especially promising in the study of "doing gender online", as research on Internet use tends to be focused on "extraordinary" users, such as hackers or gamers for example. The large number of propositions we received attests to a large interest in this perspective. The papers also confirmed that, contrarily to a common idea, it is not necessarily in the mundane aspects of life that the gender norms are the strongest, quite the contrary. While the "extraordinary" (in the meaning of the unusual or the outstanding) often relates to very specific, and therefor similar, practices, the "ordinary" covers a vast array of behaviours with complex meanings (Pasquier, 2018).

Florian Vörös's article gives a good illustration of this approach through both its topic and results. Looking at male use of pornography, the author takes interest in a very common practice. In France, nine men out of ten declare to have watched a pornographic film at least once in their life (compared to three women out of four), and half of the men declare having watched such films "often" or "sometimes" in the last twelve months (compared to one in five women). These proportions vary little according to social class. They show that pornography might be considered an exceptional phenomenon with regard to the debates and the aversion that surround it (leading many sociologists to consider it too trivial or vulgar for studying), but is nevertheless an important and mundane practice among men. When comparing men's pornographic consumption, Florian Vörös includes both heterosexual, bisexual and homosexual men, both cisgender and FTM (female to male). Like Dina Pinsky, the author does not presume differences $a$ priori depending on sexual orientation. This opens up the analysis to a variety of pornographic uses, which do not always differ depending on sexual identification.

Looking at men's relationship to pornography - in terms of use, reflexivity and potential politicisation - the author shows that "pornography is not illegitimate at all places and all times: it is mainly a problem for those men whose social status depends on cultural capital" (Vörös, 2019). Different modes of appropriation are distinguished according to two axes: the intensity of use and the attitude (positive or negative) towards it. The results show four ideal-typical ways of organising pornographic pleasures, which are satisfaction (characterised by a low and positive investment in the practice, from which stems a refusal to intellectualise it), distinction (low and negative investment from which follows a strong depreciation), control (strong and negative investment perceived as addiction) and passion (strong and positive investment as a "fan"). It is in the latter group, among the enthusiasts, that a reflexive discourse on gender relations in pornography sometimes emerges. As the author shows however, this politicisation is limited by the male entre soi: "The passion for pornography remains a pleasure discussed between men, without the women and the feminists".

Lucie Delias, on her hand, explores a diversity of femininities in her article on Internet use among French retirees, focusing on women. The text is innovative from several points of view, first and foremost for its look at senior individuals, while the study of Internet use is otherwise largely focused on young people. "Youth' is just a word" said Pierre Bourdieu, and this holds true for old age as well: living conditions, attitudes, aspirations and practices differ according to gender, social background and generation. The author shows how digital uses vary according to professional and family trajectories that are themselves closely linked to generation. The importance of the generational variable is made clear from the study of generations close in age: "the comparison of individuals 
belonging to two close cohorts shows that it is not age (or the retiree status in itself) that determine Internet use. It is rather the social, cultural and political context in which individuals evolve that influences their appropriation of new technology (Delias, 2019).

These differences between the women studied are accounted for by using a "digital autonomy" indicator. By focusing on older individuals, the author shows the importance of the past in explaining the present. The role of previous experiences is particularly important in an era of complex life course trajectories. Indeed, "individual itineraries, less permanent, are increasingly marked by alternating periods of social stability and episodes of assuring stable conditions of existence. ICT usage is largely structured by these biographical evolutions" (Granjon et al., 2009). Lucie Delias illustrates this in a convincing way. Looking at the professional background of retired women, who largely participated in the labor market, she shows that the positions held by these women (some of which were highly feminised occupations such as a secretary or teacher) determine the level of autonomy in Internet use after retirement. Also, the study of family background shows that couple life, past separations and periods of singlehood, influence digital use in different ways.

The life course perspective is often opposed to a "positional" approach focusing on differences between social groups. However, looking at trajectories does not necessarily mean doing a sociology of the individual. It mainly encourages us to adopt a dynamic approach to identifications, behaviours and groups. As Lucie Delias puts it:

The gender roles traditionally assigned to women in the professional and the private spheres, as described by materialist feminist studies (Dayan-Herzbrun, 1982, Kergoat, 2012), contribute to the way they use and perceive ICTs. However, these roles are not static but evolve over time (Delias, 2019).

Norms of femininity and masculinity are different during youth, in mid-life and at old age. They change with accumulated experiences and are due to sexual conceptions of age. This means sociologists must locate the observed gender relations within trajectories. This intersectional perspective, taking into account age, is a specific one. More than simply focusing on the consubstantial nature of different forms of stratification (gender, class, race...), it draws attention to the evolution of these very relations. Identities and behaviours change, and power relations are renegotiated and sometimes even reversed. Contrary to common approaches to stratification, that relies on an antagonistic view on social life (opposing well-constituted groups), the life course perspective focuses on transformations and reconfigurations. In the field of gender studies, this implies studying the dynamic nature of norms, identifications and practices that are neither static nor simply reproduced, but truly open to change.

\section{BIBLIOGRAPHY}

ABBATE Janet (2012). Recoding gender: Women's Changing Participation in Computing, Cambridge, MIT Press. 
ALONZo Philippe \& SILVERA Rachel (2000). « Le genre masculin n'est pas neutre », Travail, genre et sociétés, 1 (3), pp. 23-24.

AURAY Nicolas (2002). « Sociabilité informatique et différence sexuelle », in Chabaud-Rychter Danielle \& Gardey Delphine (eds.), L'engendrement des choses, des hommes, des femmes et des techniques, Paris, Éditions des Archives Contemporaines, pp. 123-148.

AURAY Nicolas (2013). Une enquête sur les institutions. Le hacker, l'Etat et la politique, Mémoire original d'Habilitation à diriger des recherches, Nice, Université de Nice Sofia Antipolis.

BACHELARD Gaston (1938). La formation de l'esprit scientifique. Contribution à une psychanalyse de la connaissance, Paris, Vrin.

BALLEYS Claire \& COLL Sami, 2015. « La mise en scène de la vie privée en ligne par les adolescents ", RESET. Recherches en sciences sociales sur Internet, 4 [online], published 2015.12.21, accessed 2019.01.01. URL: http://journals.openedition.org/reset/547.

BALLEYS Claire (2016). « “Nous les mecs”. La mise en scène de l'intimité masculine sur YouTube », in Martin Olivier \& Dagiral Éric (eds.), L'ordinaire d'internet. Le web dans nos pratiques et relations sociales, Paris, Armand Colin, pp. 182-202.

BALLEYS Claire, 2017. «L'incontrôlable besoin de contrôle. Les performances de la féminité par les adolescents sur YouTube », Genre, sexualité \& société, 17 [online], published 2017.06.01, accessed le 2017.09.25. URL : http://journals.openedition.org/gss/3958.

BERGSTRÖM Marie (2012). « Nouveaux scénarios et pratiques sexuels chez les jeunes utilisateurs de sites de rencontre », Agora débats/jeunesses, 1 (60), pp. 107-119.

BERGSTRÖM Marie (2019). Les nouvelles lois de l'amour. Sexualité, couple et rencontres au temps du numérique, Paris, La Découverte.

BREKHUS Wayne (1998). « A Sociology of the Unmarked: Redirecting Our Focus », Sociological Theory, 16 (1), pp. 34-51.

BUTLER Judith (2005). Gender trouble. Feminism and the subversion of identity, New-York, Routledge.

CLAIR Isabelle (2007). « La division genrée de l'expérience amoureuse. Enquête dans des cités d'habitat social ", Sociétés \& représentations, 2 (24), pp. 145-160.

CLAIR Isabelle (2012). « Le pédé, la pute et l'ordre hétérosexuel », Agora débats/jeunesses, 1 (60), pp. 67-78.

COLLET Isabelle (2006). L'informatique a-t-elle un sexe? Hackers, mythes et réalités, Paris, L'Harmattan.

COLLET Isabelle \& Mosconi Nicole (2010). « Les informaticiennes : de la dominance de classe aux discriminations de sexe ? ", Nouvelles questions féministes, 29 (2), pp. 100-113.

CONNELl R.W (2005). Masculinities, Berkeley, University of California Press.

DeLIAS Lucie, 2019. « Les facteurs de l'autonomie face à l'informatique connectée chez les retraités français : génération et trajectoires genrées. ", RESET. Recherches en sciences sociales sur Internet, 8 [online], URL : https://journals.openedition.org/reset/1321, published 2019.01.06, accessed le 2019.06.01.

DONNAT Olivier (2009). Les pratiques culturelles des Français à l'ère numérique, Paris, La découverte / Ministère de la culture et de la communication.

GAGNON John H. \& SIMON William (2005). Sexual conduct: The social sources of human sexuality, Piscataway, Transaction Books [1973]. 
GIRE Fabienne \& GRANJON Fabien, 2012. « Les pratiques des écrans des jeunes Français.

Déterminants sociaux et formes d'appropriation », RESET. Recherches en sciences sociales sur Internet , 1 [online], published le 2012.01.01, accessed 04.01.2012. URL : http://www.journal-reset.org/ index.php/RESET/article/view/4.

Granjon Fabien, Lelong Benoît \& METZGER Jean-Luc (2009). « Inégalités sociales, inégalités numériques : quelles articulations ? », in Granjon Fabien, Lelong Benoît \& Metzger Jean-Luc (eds.), Inégalités numériques : clivages sociaux et modes d'appropriation des TIC, Paris, Hermès science / Lavoisier, pp. 14-29.

ILlouz Eva (2006). « Réseaux amoureux sur Internet », Réseaux, 4 (138), pp. 269-272.

JenKIns Henry (1998). « Complete Freedom of Movement: Video Games as Gendered Play Spaces », in Cassell Justine \& Jenkins Henry (eds.), From Barbie to Mortal Kombat: Gender and Computer Games, Cambridge, MIT Press, pp. 262-296.

JouËT Josiane (2003). « Technologies de communication et genre », Réseaux, 4 (120), pp. 53-86.

LE DOUARIN Laurence (2004). « Hommes, femmes et micro-ordinateur : une idéologie des compétences ", Réseaux, 1 (123), pp. 149-174.

LIGNON Fanny (ed.) (2015). Genre et jeux vidéo, Toulouse, Presses universitaires du Midi.

MARDON Aurélia (2010). « Sociabilités et travail de l'apparence au collège », Ethnologie française, 40 (1), pp. 39-48.

MARDON Aurélia (2011). « La génération lolita. Stratégies de contrôle et de contournement ", Réseaux, 4-5 (168-169), pp. 111-132.

MARWICK Alice (2013). « Gender, Sexuality and Social Media », in Hunsinger Jeremy \& Senft Theresa M. (eds.), The Social Media Handbook, New-York, Routledge, pp. 59-75.

MERCKLÉ Pierre \& OCTOBRE Sylvie, 2012. « La stratification sociale des pratiques numériques des adolescents ", RESET. Recherches en sciences sociales sur Internet, 1 [online], published 2012.01.01, accessed 04.01.2012. URL : http://www.journal-reset.org/index.php/RESET/article/view/3.

MISA Thomas J. (2011). Gender codes: Why Women are Leaving Computing, Hoboken, John Wiley \& Sons.

OстовRE Sylvie (2011). « Du féminin et du masculin : genre et trajectoires culturelles », Réseaux, 4 (168-169), pp. 23-57.

OUdSHOoRn Nelly, Rommes Els \& STIENSTRA Marcelle (2004). « Configuring the User as Everybody: Gender and Design Cultures in Information and Communication Technologies ", Science, Technology, \& Human Values, 29 (1), pp. 30-63.

PASQUIER Dominique (2018). L'Internet des familles modestes. Enquête dans la France rurale, Paris, Presses des Mines.

RHEINGOLD Howard (1993). The Virtual Community: Homesteading on the Electronic Frontier, Reading, Addison-Wesley.

SINGH Supriya (2001). « Gender and the use of the Internet at home », New Media \& Society, 3 (4), pp. 395-415.

STONE ALLUCQUÈre Rosanne (1995). The War of Desire and Technology at the Close of the Mechanical Age, Cambridge, MIT Press. 
TURKLE Sherry (1988). « Computational Reticence: Why Women Fear the Intimate Machine », in Kramarae Cheris (ed.), Technology and Women's voices: Keeping in touch, New-York, Routledge, pp. 41-61.

TURKLE Sherry (1995). Life On The Screen. Identity In The Age of The Internet, New-York, Simon \& Schuster Paperbacks.

\section{NOTES}

1. Source : Insee, census, 2014.

\section{AUTHORS}

\section{MARIE BERGSTRÖM}

Institut national d'études démographiques

\section{DOMINIQUE PASQUIER}

CNRS / Télécom ParisTech 